\title{
Iron oxides as weathering indicator and the origin of Luvisols from the Vistula glaciation region in Poland
}

\author{
Hanna Jaworska $^{1}$ - Halina Dąbkowska-Naskręt ${ }^{1}$ • Mirosław Kobierski ${ }^{1}$
}

Received: 10 March 2015 / Accepted: 9 July 2015 / Published online: 30 July 2015

(C) The Author(s) 2015. This article is published with open access at Springerlink.com

\begin{abstract}
Purpose The aim of the research was to determine the effect of lithogenic and pedogenic processes on the formation of Luvisols from the area of Vistula glaciation on the base of profile distribution of iron oxides and total iron in relation to texture and physicochemical properties. The indices of weathering of the soil material in genetic horizons were calculated, and changes in the content and forms of iron oxides were evaluated.

Materials and methods The predominant type of soil in the study area is Luvisols under agricultural use, formed from silt formations on loam. The analyses were made applying the following methods: grain size composition using the sieve method and hydrometer method, the interpretation of the results was performed according to the World Reference Base for Soil Resources classification, the $\mathrm{pH}$ of soils was measured with the potentiometric method, C-organic with the WalkleyBlack dichromate method, the content of the following iron forms was determined (total iron $\left(\mathrm{Fe}_{\mathrm{t}}\right)$ after the mineralization of soils in the mixture of $\mathrm{HF}$ and $\mathrm{HClO}_{4}$ acids), free iron oxides were extracted using dithionite-citrate-bicarbonate method, and amorphous iron oxides after the ammonium oxalate extraction (using the Philips 9100PU apparatus). The clay mineralogy was estimated by X-ray diffraction analysis. Results and discussion It was observed that total iron enrichment occurs in argic horizons accompanied by iron depletion
\end{abstract}

Responsible editor: Fabio Scarciglia

Hanna Jaworska

hjawor@utp.edu.pl

1 Department of Soil Science and Soil Protection, Faculty of Agriculture and Biotechnology, UTP University of Science and Technology, Bernardyńska 6 St, 85-029 Bydgoszcz, Poland in luvic horizons, while the profile distribution of iron is similar to the distribution of clay. The $\left(\mathrm{Fe}_{\mathrm{d}} / \mathrm{Fe}_{\mathrm{t}}\right)$ ratio indicates a low degree of weathering; the highest values were observed in $\operatorname{argic}(\mathrm{Bt})$ horizons, which confirms the effect of the process of pedogenesis on the value of that index. In the soils investigated, crystalline iron oxides generally dominate over the amorphous forms. The mineralogical composition of clay fraction separated from the upper part of soils was different as compared to the underlying material.

Conclusions The results of the study showed that iron contents (together with the other indicators) and its forms can be used to distinguish soil layers of different origin. The depth distribution of $\mathrm{Fe}_{\mathrm{d}}, \mathrm{Fe}_{\mathrm{o}}$ and $\mathrm{Fe}_{\mathrm{t}}$ within soil profiles indicates that the soil material may be of different lithogenic origin in the studied pedons.

Keywords Iron oxides $\cdot$ Lithogenesis $\cdot$ Luvisols $\cdot$ Pedogenesis · Vistula glaciation

\section{Introduction}

The Pleistocene deposits formed as a result of Scandinavian continental glaciations cover much of northern and central Poland. The Vistula glaciation in Poland is consistent with the Weichsel glaciation in Germany, the Warta glaciation (Lindner 1984) in the eastern part of Europe, and the Wisconsin glaciation (Flint 1971) in North America and accounts for the formation of glacial deposits with various morphological and physicochemical properties. Date ranges for the Poznan phase and Kujawsko-Dobrzynska subphase are $18400 \mathrm{kaBP}$ (Wysota et al. 2008). The Luvisols is formed during the Kujawy-Dobrzyń subphase of the Vistula glaciation demonstrating a morphological profile variation, which could be due to the processes of lithogenesis and pedogenesis. The 
soil formation processes in the Luvisol profiles result in the differentiation of the chemical and mineralogical composition of soil material (Ranney and Beatty 1969).

One of the generally accepted methods in research on soil genesis is the analysis of iron forms, depending on the direction of the soil-forming processes, their type and intensity (Blume and Schwertmann 1969; Cornell and Schwertmann 2003). The iron compounds, especially their complex associations with humus colloids, determine the profile distribution of other elements (Tack et al. 1997) in soils. They affect the colour of soils and are indicators of their properties (Kabata-Pendias and Pendias 2010). Soils containing goethite are yellow or brown. Ferrihydrite is dark reddish-brown. Variations in crystal size and morphology may cause variations in these mineralspecific colours. With decreasing particle size, the colour of goethite changes from yellow for crystals in the micrometre size range to dark brown for crystals of ca. $0.01 \mu \mathrm{m}$ in length. Mn for Fe substitution causes goethite to develop on olive (1-6\% Mn) to blackish colour (10\% Mn) (Schwertmann and Cornell 1991). Iron dynamics can be studied by different extractions. The ratio of oxalate to dithionite-extractable iron $\left(\mathrm{Fe}_{\mathrm{o}} / \mathrm{Fe}_{\mathrm{d}}\right)$ indicates the degree of iron oxide crystallinity and can be used as a reliable indicator of soil age (McFadden and Hendricks 1985). Hence, the $\mathrm{Fe}_{\mathrm{o}} / \mathrm{Fe}_{\mathrm{d}}$ ratio tends to decrease with soil age (Moody and Graham 1995). The absence of a clear time trend of $\mathrm{Fe}_{\mathrm{o}} / \mathrm{Fe}_{\mathrm{d}}$ ratio can be explained by other factors (climatic conditions, parent material, redox processes and organic matter content) having greater impact on the $\mathrm{Fe}_{\mathrm{o}} / \mathrm{Fe}_{\mathrm{d}}$ ratio than the time factor. The degree of weathering and formation of pedogenic iron oxides and hydroxides is expressed by the ratio of $\mathrm{Fe}_{\mathrm{d}} / \mathrm{Fe}_{\mathrm{t}}$. An increasing $\mathrm{Fe}_{\mathrm{d}} / \mathrm{Fe}_{\mathrm{t}}$ ratio reflects the progressive weathering of $\mathrm{Fe}$ bearing minerals with time (Arduino et al. 1986).

Soils formed from glacial deposits often show genetic heterogeneity and lithological discontinuity (Birkeland 1999; Kühn 2001). Defining the relationship between lithogenesis and pedogenesis is one of the key problems on studying those soils. Evaluating the soil-formation pattern and the origin of soils based on the chemical composition of the soil mass requires reference to soil parent materials.

The aim of the present study was to determine the effect of lithogenesis and pedogenesis on the formation of Luvisols from Vistula glaciation sediments on the base of profile distribution of iron compounds, particularly iron oxides and hydroxides in relation to texture, the content of hardly weathered mineral-zircon, clay mineralogy and the physicochemical properties of soils.

\section{Material and methods}

The soil profiles selected for the study are located in the area of the South Pomerania Lake District on the flat bottommoraine plains formed during the Vistula stadial, the Poznan stage (Lindner 1992). Luvisols (IUSS Working Group WRB 2007) are predominant and under agricultural use, formed from silt formations on loam, with the following genetic horizon sequence: Ap-Et-Bt-C. Soil texture and the morphology of soil pedons suggest a lithological discontinuity within soil profiles in the region. Selected profiles were located on the flat area of ground moraine plane formed during the Poznań Phase of the Vistula Glaciation (Lindner 1984; Marks 2002). The samples for analyses were taken from the each genetic horizon of seven profiles. The location of the soil profiles (P1Zarzeczewo; P2-Glewo; P3-Dyblin; P4-Strachoń; P5Mokowo; P6-Grochowalsk; P7-Bachorzewo) was determined by using a GPS system (Fig. 1, Table 1).

The analyses were made applying the following methods: grain size composition using the hydrometer method, based on Stoke's law governing the rate of sedimentation of particles suspended in water, the interpretation of the results is based on the World Reference Base for Soil Resources classification (IUSS Working Group WRB 2007), the pH of soils was measured with the potentiometric method $(\mathrm{pH}$ in $\mathrm{KCl}$ $\left(1 \mathrm{~mol} \mathrm{dm}^{-3}\right)$ and $\mathrm{pH}$ in $\left.\mathrm{H}_{2} \mathrm{O}\right)$, C-organic with the WalkleyBlack dichromate method, and the content of the following iron forms was determined:

- Total iron $\left(\mathrm{Fe}_{\mathrm{t}}\right)$ after the mineralization of soils in the mixture of $\mathrm{HF}$ and $\mathrm{HClO}_{4}$ acids (Crock and Severson 1980)

- Free iron oxides $\left(\mathrm{Fe}_{\mathrm{d}}\right)$ were extracted using dithionitecitrate-bicarbonate method according to Mehra-Jackson (Mehra and Jackson 1960)

- Amorphous iron oxides (Feo) after ammonium oxalate extraction according to Tamm (Schlichting and Blume 1962) with the ASA method (using the Philips 9100PU apparatus)

The total content of zirconium in the soil samples was determined by the fusion of soil with potassium pyrosulphate, and its concentration in the solutions was determined with the spectrofluorimeter Hitachi F-2000 according to Wang et al. (2000).

For the characterization of lithogenic and pedogenic processes in the soils, the following indices were calculated:

- Weathering index $\left(\mathrm{Fe}_{\mathrm{d}} / \mathrm{Fe}_{\mathrm{t}}\right)$

- Iron activity index $\left(\mathrm{Fe}_{\mathrm{o}} / \mathrm{Fe}_{\mathrm{d}}\right)$

- Crystalline iron content $\left(\mathrm{Fe}_{\mathrm{c}}=\mathrm{Fe}_{\mathrm{d}}-\mathrm{Fe}_{\mathrm{o}}\right)$

Micromorphology study was done on undisturbed soil samples collected from the selected horizons of the studied profiles. The micromorphological features were described according to Fitzpatrick (1984). The thin sections were interpreted using the nomenclature of Stoops (2003).

The clay mineralogy was estimated by X-ray diffraction analysis of the clay fraction $(<2 \mu \mathrm{m})$ separated by centrifugation on 

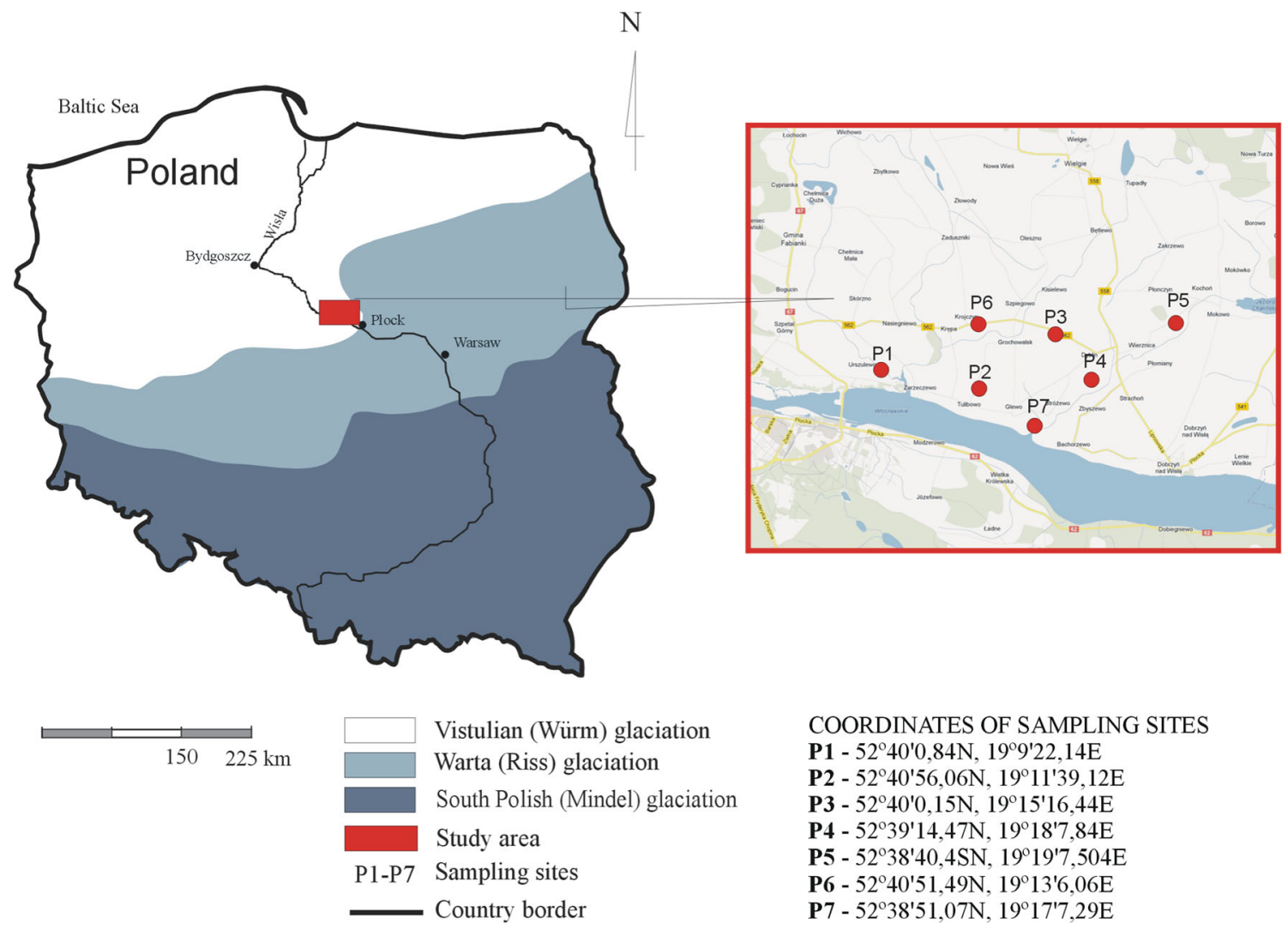

COORDINATES OF SAMPLING SITES

P1 - $52^{\circ} 40^{\prime} 0,84 \mathrm{~N}, 19^{\circ} 9^{\prime} 22,14 \mathrm{E}$

P2 - 52 $2^{\circ} 40^{\prime} 56,06 \mathrm{~N}, 19^{\circ} 11^{\prime} 39,12 \mathrm{E}$

P3 $-52^{\circ} 40^{\prime} 0,15 \mathrm{~N}, 1^{\circ} 15^{\prime} 16,44 \mathrm{E}$

P4 - $52^{\circ} 39^{\prime} 14,47 \mathrm{~N}, 19^{\circ} 18^{\prime} 7,84 \mathrm{E}$

P5 - 52 $38^{\prime} 40,4 \mathrm{SN}, 19^{\circ} 19^{\prime} 7,504 \mathrm{E}$

P6 - 52 $42^{\circ} 51,49 \mathrm{~N}, 19^{\circ} 13^{\prime} 6,06 \mathrm{E}$

P7 - 52 $2^{\circ} 38^{\prime} 51,07 \mathrm{~N}, 19^{\circ} 17^{\prime} 7,29 \mathrm{E}$

Fig. 1 Research area

parallel (oriented specimens), Mg (saturated), Mg (saturated and ethylene glycol solvated), $\mathrm{K}$ (saturated) and $\mathrm{K}$ (saturated after heating at $550{ }^{\circ} \mathrm{C}$ ). Analyses were performed on X-Pert Powder instrument, with $\mathrm{Cuk} \alpha$ radiation at $30 \mathrm{~mA}, 40 \mathrm{kV}$.

Statistical evaluation of results was performed using Statistica 10 software by setting Pearson's linear correlation coefficients.

\section{Results and discussion}

The soils were classified as Haplic Luvisols (IUSS Working Group WRB 2007). The following genetic horizons were identified: Ap-Et-Bt-C. The feature differentiating the soils is the variation in thickness of diagnostic horizons: Et and $\mathrm{Bt}$, across the profiles, which suggests a varied intensity of the illuvial process occurring in studied

Table 1 Location and geographic coordinates of the profiles

\begin{tabular}{|c|c|c|c|c|c|c|c|}
\hline Profile no. & Location & District & Physiographic entity & $\begin{array}{l}\text { Geographic } \\
\text { coordinates }\end{array}$ & $\mathrm{m}$ a.s.1. & Climate & $\begin{array}{l}\text { Parent } \\
\text { material }\end{array}$ \\
\hline \multirow[t]{2}{*}{ P1 } & \multirow[t]{2}{*}{ Zarzeczewo } & South Pomerania Lake & \multirow{14}{*}{$\begin{array}{l}\text { ground } \\
\text { moraine plane }\end{array}$} & $52^{\circ} 40^{\prime} 0.84 \mathrm{~N}$ & 90 & \multirow{14}{*}{$\begin{array}{l}\text { Continental } \\
\text { Sea } \\
\text { Mean annual temperature } \\
\text { Total annual precipitation } \\
530 \mathrm{~mm}^{\mathrm{a}}\end{array}$} & Silt/loam \\
\hline & & Northern Poland & & $19^{\circ} 9^{\prime} 22.14 \mathrm{E}$ & & & \\
\hline \multirow[t]{2}{*}{ P2 } & \multirow[t]{2}{*}{ Glewo } & & & $52^{\circ} 40^{\prime} 56.06 \mathrm{~N}$ & 84 & & \\
\hline & & & & $19^{\circ} 11^{\prime} 39.12 \mathrm{E}$ & & & \\
\hline \multirow[t]{2}{*}{ P3 } & \multirow[t]{2}{*}{ Dyblin } & & & $52^{\circ} 40^{\prime} 0.15 \mathrm{~N}$ & 89 & & \\
\hline & & & & $19^{\circ} 15^{\prime} 16.44 \mathrm{E}$ & & & \\
\hline \multirow[t]{2}{*}{ P4 } & \multirow[t]{2}{*}{ Strachoń } & & & $52^{\circ} 39^{\prime} 14.47 \mathrm{~N}$ & 98 & & \\
\hline & & & & $19^{\circ} 18^{\prime} 7.84 \mathrm{E}$ & & & \\
\hline \multirow[t]{2}{*}{ P5 } & \multirow[t]{2}{*}{ Mokowo } & & & $52^{\circ} 38^{\prime} 40.4 \mathrm{SN}$ & 98 & & \\
\hline & & & & $19^{\circ} 19^{\prime} 7.504 \mathrm{E}$ & & & \\
\hline \multirow[t]{2}{*}{ P6 } & \multirow[t]{2}{*}{ Grochowalsk } & & & $52^{\circ} 40^{\prime} 51.49 \mathrm{~N}$ & 95 & & \\
\hline & & & & $19^{\circ} 13^{\prime} 6.06 \mathrm{E}$ & & & \\
\hline \multirow[t]{2}{*}{$\mathrm{P} 7$} & \multirow[t]{2}{*}{ Bachorzewo } & & & $52^{\circ} 38^{\prime} 51.07 \mathrm{~N}$ & 90 & & \\
\hline & & & & $19^{\circ} 17^{\prime} 7.29 \mathrm{E}$ & & & \\
\hline
\end{tabular}

\footnotetext{
${ }^{\mathrm{a}}$ For each pedon
} 
soils (Jaworska et al. 2014). The studied sites are located on the flat area of ground moraine plain (Lindner 1984), and there are no available data or evidence of erosion and/or redeposition processes causing such a difference in soil morphology.

Textural analysis allow for separating the following granulometric groups: silty loam, in the substratum of which loam is found (Table 2), except for horizon Ap in profile P1, where loam occurred deep down to $30 \mathrm{~cm}$, and then sandy silt occurred with underlying loam (Table 2), similarly in horizons
Ap and Et in profile P5, deep down to 35-cm silty loam, underlying with loam, occurred.

Soil texture varies with depth within studied profiles. They are mainly silty loams with loamy material as their subsoil.

Generally, surface horizons contain $20-55 \%$ of silt $(0.05-$ $0.002 \mathrm{~mm}$ ), which corresponds to a silty loam texture. Illuvial horizons and parent material contain 16-52\% silt and 4-29\% clay, classifying them as loamy soils. The discontinuity in the grain size distribution within profiles may result from either lessivage or periglacial processes. The clay content changes

Table 2 Selected properties and texture of soils grams per kilogram

\begin{tabular}{|c|c|c|c|c|c|c|c|c|c|c|c|}
\hline \multirow[t]{2}{*}{ No. } & \multirow[t]{2}{*}{ Horizon } & \multirow{2}{*}{$\begin{array}{l}\text { Depth } \\
\text { (cm) }\end{array}$} & \multirow{2}{*}{$\begin{array}{l}\mathrm{pH} \\
\left(\mathrm{H}_{2} \mathrm{O}\right)\end{array}$} & \multirow{2}{*}{$\begin{array}{l}\mathrm{pH} \\
(1 \mathrm{MKCl})\end{array}$} & \multirow{2}{*}{$\begin{array}{l}\mathrm{CEC} \\
\left(\mathrm{cmol}^{+} \mathrm{kg}^{-1}\right)\end{array}$} & \multirow{2}{*}{$\begin{array}{l}\mathrm{CaCO}_{3} \\
(\%)\end{array}$} & \multirow{2}{*}{$\begin{array}{l}\text { Corg. } \\
\left(\mathrm{g} \mathrm{kg}^{-1}\right)\end{array}$} & \multicolumn{3}{|c|}{ Content of fraction $(\%)$} & \multirow[t]{2}{*}{ Silt/clay } \\
\hline & & & & & & & & $2-0.05$ & $0.05-0.002$ & $<0.002$ & \\
\hline \multirow[t]{5}{*}{ P1 } & Ap & $0-30$ & 6.40 & 6.24 & 14.3 & - & 8.2 & 60 & 38 & 2 & 19.0 \\
\hline & Et & $30-56$ & 7.07 & 6.99 & 10.4 & - & 2.1 & 41 & 57 & 2 & 28.5 \\
\hline & $2 \mathrm{Bt} 1$ & $56-98$ & 6.92 & 6.60 & 23.3 & - & 1.3 & 54 & 29 & 17 & 1.7 \\
\hline & $2 \mathrm{Bt} 2$ & $98-110$ & 7.52 & 7.45 & 30.1 & - & 0.0 & 48 & 32 & 19 & 1.7 \\
\hline & $2 \mathrm{C}$ & $110-150$ & 8.14 & 8.00 & 25.6 & Trace & 0.0 & 63 & 26 & 11 & 2.4 \\
\hline \multirow[t]{5}{*}{$\mathrm{P} 2$} & Ap & $0-25$ & 7.24 & 7.03 & 22.2 & - & 10.0 & 46 & 46 & 8 & 5.8 \\
\hline & Et & $25-43$ & 7.51 & 7.14 & 14.0 & - & 1.9 & 46 & 49 & 6 & 8.2 \\
\hline & $2 \mathrm{Bt}$ & $43-110$ & 7.35 & 6.30 & 25.3 & - & 1.5 & 57 & 28 & 15 & 1.9 \\
\hline & $2 \mathrm{Ck} 1$ & $110-130$ & 7.95 & 7.46 & 24.5 & 3.8 & 0.0 & 65 & 21 & 14 & 1.5 \\
\hline & $2 \mathrm{Ck} 2$ & $130-150$ & 7.93 & 7.59 & 39.1 & 4.2 & 0.0 & 66 & 21 & 13 & 1.6 \\
\hline \multirow[t]{5}{*}{ P3 } & Ap & $0-25$ & 6.21 & 5.80 & 12.6 & - & 13.0 & 48 & 48 & 4 & 12.0 \\
\hline & Et & $25-40$ & 6.84 & 6.44 & 10.8 & - & 1.7 & 40 & 55 & 5 & 11.0 \\
\hline & $2 \mathrm{Bt}$ & $40-95$ & 8.07 & 7.21 & 27.5 & - & 1.2 & 62 & 21 & 17 & 1.2 \\
\hline & $2 \mathrm{Ckg} 1$ & $95-125$ & 8.48 & 7.87 & 29.4 & 3.5 & 0.0 & 56 & 29 & 15 & 1.9 \\
\hline & $2 \mathrm{Ck} 2$ & $125-150$ & 8.48 & 7.85 & 32.1 & 4.4 & 0.0 & 55 & 30 & 15 & 2.0 \\
\hline \multirow[t]{5}{*}{ P4 } & Ap & $0-30$ & 5.98 & 5.50 & 12.4 & - & 11.6 & 42 & 49 & 9 & 5.4 \\
\hline & Et & $30-50$ & 6.45 & 5.94 & 12.1 & - & 3.2 & 46 & 50 & 4 & 12.5 \\
\hline & $2 \mathrm{Bt}$ & $50-80$ & 7.81 & 6.92 & 21.5 & - & 1.2 & 63 & 25 & 12 & 2.1 \\
\hline & $2 \mathrm{C}$ & $80-120$ & 7.84 & 7.04 & 19.3 & Trace & 0.0 & 67 & 23 & 10 & 2.3 \\
\hline & $2 \mathrm{Ck}$ & $120-150$ & 7.59 & 6.77 & 25.4 & 2.6 & 0.0 & 68 & 25 & 7 & 3.6 \\
\hline \multirow[t]{5}{*}{ P5 } & Ap & $0-22$ & 7.21 & 6.80 & 11.1 & - & 11.1 & 57 & 39 & 4 & 9.8 \\
\hline & Et & $22-35$ & 6.84 & 6.34 & 15.9 & - & 4.5 & 55 & 42 & 3 & 14.0 \\
\hline & $2 \mathrm{Bt}$ & $35-110$ & 8.01 & 7.01 & 17.0 & - & 1.3 & 67 & 18 & 15 & 1.2 \\
\hline & $2 \mathrm{BC}$ & $110-130$ & 6.93 & 6.85 & 16.1 & - & 0.0 & 66 & 21 & 13 & 1.6 \\
\hline & $2 \mathrm{C}$ & $130-150$ & 7.31 & 7.06 & 6.6 & Trace & 0.0 & 66 & 24 & 10 & 2.4 \\
\hline \multirow[t]{5}{*}{ P6 } & Ap & $0-20$ & 7.85 & 7.73 & 11.1 & - & 11.2 & 55 & 44 & 1 & 44.0 \\
\hline & Et & $20-42$ & 7.73 & 7.27 & 14.9 & - & 1.9 & 52 & 46 & 2 & 23.0 \\
\hline & $2 \mathrm{~EB}$ & $42-90$ & 7.80 & 7.75 & 17.4 & - & 0.9 & 61 & 31 & 8 & 3.9 \\
\hline & $2 \mathrm{Bt}$ & $90-130$ & 7.42 & 6.38 & 15.3 & - & 0.0 & 62 & 23 & 15 & 1.5 \\
\hline & $2 \mathrm{C}$ & $130-150$ & 7.47 & 6.82 & 14.8 & - & 0.0 & 61 & 29 & 10 & 1.6 \\
\hline \multirow[t]{5}{*}{ P7 } & Ap & $0-23$ & 7.23 & 6.65 & 12.5 & - & 9.9 & 49 & 43 & 8 & 5.4 \\
\hline & Et & $23-43$ & 8.02 & 7.59 & 12.7 & Trace & 3.2 & 36 & 54 & 10 & 5.4 \\
\hline & $2 \mathrm{EBg}$ & $43-61$ & 8.02 & 7.15 & 20.4 & - & 1.3 & 69 & 23 & 8 & 2.9 \\
\hline & $2 \mathrm{Btg}$ & $61-111$ & 7.82 & 6.65 & 19.5 & - & 0.0 & 63 & 20 & 17 & 1.2 \\
\hline & $2 \mathrm{Cg}$ & $111-150$ & 8.06 & 7.54 & 18.7 & - & 0.0 & 63 & 26 & 11 & 2.4 \\
\hline
\end{tabular}


abruptly between Et and Bt horizons reflecting a change in parent material. The enrichment in clay particles in deeper horizons (Table 2) may result from clay illuviation, but according to Kühn (2003), it may be also due to a silty-cover bed above glacigenic material. The silt/clay ratio used as a measure of the uniformity of soil material within profile may prove the occurrence of two layers (Wagner et al 2007). Changes in the silt/clay ratio between layers reflect the major influence of the parent materials. Calculated silt/clay ratios in the upper part of analysed soil profiles (A and Et horizons) are

Table 3 Content of total iron $\left(\mathrm{Fe}_{\mathrm{t}}\right)$, iron extracted with dithionitecitrate-bicarbonate $\left(\mathrm{Fe}_{\mathrm{d}}\right)$, iron extracted with ammonium oxalate $\left(\mathrm{Fe}_{\mathrm{o}}\right)$, total zirconium (Zrt) and crystallinity index $\left(\mathrm{Fe}_{\mathrm{o}} / \mathrm{Fe}_{\mathrm{d}}\right)$, weathering index $\left(\mathrm{Fe}_{\mathrm{d}} / \mathrm{Fe}_{\mathrm{t}}\right)$ and crystalline iron $\left(\mathrm{Fe}_{\mathrm{c}}=\mathrm{Fe}_{\mathrm{d}}-\mathrm{Fe}_{\mathrm{o}}\right)$

\begin{tabular}{|c|c|c|c|c|c|c|c|c|}
\hline No. & Horizon & $\mathrm{Fe}_{\mathrm{t}}\left(\mathrm{g} \mathrm{kg}^{-1}\right)$ & $\mathrm{Fe}_{\mathrm{d}}$ & $\mathrm{Fe}_{\mathrm{o}}$ & $\mathrm{Fe}_{\mathrm{c}}$ & $\mathrm{Zrt}$ & $\mathrm{Fe}_{\mathrm{o}} / \mathrm{Fe}_{\mathrm{d}}$ & $\mathrm{Fe}_{\mathrm{d}} / \mathrm{Fe}$ \\
\hline \multirow[t]{5}{*}{ P1 } & Ap & 7.89 & 2.52 & 0.99 & 1.53 & 0.11 & 0.39 & 0.32 \\
\hline & Et & 7.17 & 1.85 & 0.97 & 0.88 & 0.12 & 0.52 & 0.26 \\
\hline & Bt1 & 16.06 & 7.35 & 2.08 & 5.27 & 0.14 & 0.28 & 0.46 \\
\hline & $2 \mathrm{Bt} 2$ & 14.63 & 5.82 & 1.03 & 4.79 & 0.10 & 0.18 & 0.40 \\
\hline & $2 \mathrm{C}$ & 13.47 & 4.31 & 0.37 & 3.94 & 0.09 & 0.09 & 0.32 \\
\hline \multirow[t]{5}{*}{$\mathrm{P} 2$} & Ap & 5.67 & 2.36 & 1.20 & 1.16 & 0.15 & 0.51 & 0.42 \\
\hline & Et & 16.65 & 1.90 & 1.23 & 0.67 & 0.16 & 0.65 & 0.11 \\
\hline & $2 \mathrm{Bt}$ & 14.64 & 3.24 & 1.38 & 1.86 & 0.10 & 0.43 & 0.22 \\
\hline & $2 \mathrm{Ck} 1$ & 9.21 & 3.41 & 0.36 & 3.05 & 0.11 & 0.11 & 0.37 \\
\hline & $2 \mathrm{Ck} 2$ & 13.23 & 3.36 & 0.43 & 2.93 & 0.12 & 0.13 & 0.25 \\
\hline \multirow[t]{5}{*}{ P3 } & Ap & 8.03 & 1.60 & 0.74 & 0.86 & 0.14 & 0.46 & 0.20 \\
\hline & $\mathrm{Et}$ & 8.03 & 1.02 & 0.79 & 0.24 & 0.17 & 0.77 & 0.13 \\
\hline & $2 \mathrm{Bt}$ & 16.02 & 3.93 & 1.20 & 2.73 & 0.12 & 0.31 & 0.25 \\
\hline & $2 \mathrm{Ckg} 1$ & 14.34 & 2.52 & 0.70 & 1.82 & 0.10 & 0.28 & 0.18 \\
\hline & $2 \mathrm{Ck} 2$ & 15.37 & 3.68 & 0.42 & 3.26 & 0.09 & 0.11 & 0.24 \\
\hline \multirow[t]{5}{*}{ P4 } & Ap & 7.79 & 2.35 & 0.87 & 1.98 & 0.19 & 0.16 & 0.30 \\
\hline & Et & 10.43 & 3.34 & 1.04 & 2.30 & 0.17 & 0.31 & 0.32 \\
\hline & $2 \mathrm{Bt}$ & 15.95 & 5.71 & 1.34 & 4.37 & 0.11 & 0.23 & 0.36 \\
\hline & $2 \mathrm{C}$ & 14.23 & 4.26 & 1.29 & 2.97 & 0.13 & 0.30 & 0.30 \\
\hline & $2 \mathrm{Ck}$ & 11.10 & 2.83 & 0.79 & 2.04 & 0.11 & 0.28 & 0.25 \\
\hline \multirow[t]{5}{*}{ P5 } & Ap & 8.34 & 2.40 & 1.08 & 1.32 & 0.17 & 0.45 & 0.29 \\
\hline & $\mathrm{Et}$ & 8.09 & 2.00 & 1.23 & 0.77 & 0.18 & 0.62 & 0.25 \\
\hline & $2 \mathrm{Bt}$ & 16.36 & 4.81 & 1.36 & 3.45 & 0.10 & 0.28 & 0.29 \\
\hline & $2 \mathrm{BC}$ & 14.81 & 4.10 & 0.36 & 3.74 & 0.10 & 0.09 & 0.28 \\
\hline & $2 \mathrm{C}$ & 15.84 & 2.95 & 0.43 & 2.52 & 0.10 & 0.15 & 0.19 \\
\hline \multirow[t]{5}{*}{ P6 } & Ap & 9.09 & 2.07 & 1.07 & 1.00 & 0.16 & 0.52 & 0.23 \\
\hline & Et & 7.99 & 2.39 & 0.92 & 1.47 & 0.16 & 0.38 & 0.30 \\
\hline & $2 \mathrm{~EB}$ & 13.27 & 6.41 & 1.34 & 5.07 & 0.15 & 0.21 & 0.48 \\
\hline & $2 \mathrm{Bt}$ & 8.32 & 6.09 & 0.97 & 5.12 & 0.09 & 0.16 & 0.73 \\
\hline & $2 \mathrm{C}$ & 9.07 & 7.36 & 1.03 & 6.33 & 0.11 & 0.14 & 0.81 \\
\hline \multirow[t]{5}{*}{ P7 } & Ap & 12.25 & 2.36 & 0.90 & 1.46 & 0.17 & 0.38 & 0.19 \\
\hline & Et & 13.88 & 2.00 & 0.94 & 1.06 & 0.20 & 0.47 & 0.14 \\
\hline & $2 \mathrm{EBg}$ & 21.54 & 5.55 & 1.55 & 4.00 & 0.17 & 0.28 & 0.26 \\
\hline & 2Btg & 19.05 & 5.80 & 1.16 & 4.64 & 0.12 & 0.20 & 0.30 \\
\hline & $2 \mathrm{Cg}$ & 18.51 & 3.70 & 0.47 & 3.23 & 0.12 & 0.13 & 0.20 \\
\hline
\end{tabular}

noticeably higher compared to underlying $\mathrm{Bt}$ and $\mathrm{C}$ horizons (Table 2). This might be connected with the different origin of upper layer. A similar texture differentiation was reported by Kühn (2003). The genesis of so-called silty cover-bed (Kopp and Kowalkowski 1990) is mostly of Holocene pedogenic origin. It is however accepted that during the Late Weichselian processes like repeated freeze-thaw cycles, cryoturbation and also eolian input, etc. led to the formation of the so-called silty cover bed (Kopp and Kowalkowski 1990). The variety of factors that lead to the formation of these soils might interfere causing a complex mixture of processes responsible for the formation of solum. This applies particularly to soils characterized by vertical differentiation of mineral material, frequently encountered among the glacial deposits. The values of typological indicators (Table 3 ) indicate that the soil material may be of different origin in the studied pedons.

The presence of two sola in the studied profiles is also expressed by cation exchange capacity (CEC) (Table 2). The cation exchange capacity values are distinctly lower in the top soil than in the underlying material, indicating some discontinuity.

Soil $\mathrm{pH}$ is in the range of 5.5-8.0 (Table 2). Lower $\mathrm{pH}$ values were observed in surface horizons with silty loam texture (Table 2). The soils are generally deficient in $\mathrm{CaCO}_{3}$. The parent material, in profiles $\mathrm{P} 1, \mathrm{P} 2, \mathrm{P} 3, \mathrm{P} 4$ and $\mathrm{P} 5$, is the only location where $\mathrm{CaCO}_{3}$ occurs in the range 2.6 to $4.4 \%$. Carbonate-leaching is typical for this type of soils (Dąbkowska- Naskręt and Jaworska 1997). The soils analysed contain $8.29-12.98 \mathrm{~g} \mathrm{~kg}^{-1}$ of organic carbon. A low content of organic matter is characteristic for arable Luvisols due to the dominance of mineralization over humification process of organic remains (Haynes 2005). The intensity of those processes mainly depends on the air-and-water conditions and the type of land use.

The distribution of different forms of $\mathrm{Fe}$ within profiles is shown in Table 3. The content of total iron $\left(\mathrm{Fe}_{t}\right)$ ranged from 7.17 to $21.54 \mathrm{~g} \mathrm{~kg}^{-1}$ (Table 3).

The lowest $\mathrm{Fe}_{t}$ contents occurred in $\mathrm{A}_{\mathrm{p}}$ horizons of all the investigated profiles (Table 3). The profile distribution of $\mathrm{Fe}_{\mathrm{t}}$ was similar to the clay distribution, indicating a secondary illuviation of iron with clay (Deng et al. 1998). Since hydrous $\mathrm{Fe}$ oxides are often associated with clay minerals (Kabata-

Table 4 Significant correlation coefficients $(p<0.05)$

\begin{tabular}{lllll}
\hline Variable & $\mathrm{Fe}_{\mathrm{t}}$ & $\mathrm{Fe}_{\mathrm{d}}$ & $\mathrm{Fe}_{\mathrm{o}}$ & $\mathrm{Fe}_{\mathrm{C}}$ \\
\hline Clay fraction & $0.584^{*}$ & $0.602^{*}$ & & $0.641^{*}$ \\
$\mathrm{Fe}_{\mathrm{d}}$ & $0.457^{*}$ & & $0.381^{*}$ & $0.973^{*}$ \\
$\mathrm{Fe}_{\mathrm{c}}$ & $0.440^{*}$ & & & \\
Corg & $-0.549^{*}$ & $-0.505^{*}$ & 0.102 & $-0.547^{*}$ \\
\hline
\end{tabular}

*Significant 
Fig. 2 Weathering index values

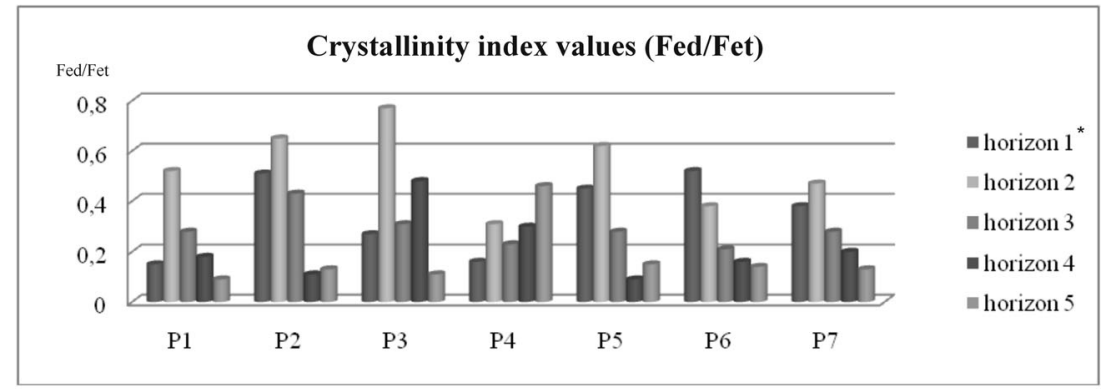

* Numbers related to genetic horizons described in Table 1

Pendias and Pendias 2010), the $\mathrm{Fe}_{\mathrm{d}}$ content correlates significantly with the content of clay fraction in the studied soils $(r=$ $0.602, p<0.05$ ) (Table 4). The relationship between $\mathrm{Fe}_{\mathrm{t}}$ content and soil texture mostly on the content of fraction $<0.002 \mathrm{~mm}$ was also reported by Muhs et al. (2001). Due to chemical weathering of silicates and aluminosilicates and because of the mineralization of organic residue, releasing iron oxides can be accompanied by a slight increase in the clay fraction (Duchaufour and Sochiers 1978).

The contents of free pedogenic iron $\left(\mathrm{Fe}_{\mathrm{d}}\right)$ varied across the profiles, similarly as the contents of total iron (Table 3). The highest contents were found in Bt horizons, accompanied by the depletion in Et horizons, which points to eluviation of free iron with clay by lessivage (Schlichting and Blume 1962). Secondary iron oxides are much smaller particles than $2 \mu \mathrm{m}$ (usually less than $500 \mathrm{~nm}$ ); they are therefore mostly components of the colloidal fraction (Waychunas et al. 2005).

The ratio of free iron to total iron $\left(\mathrm{Fe}_{\mathrm{d}} / \mathrm{Fe}_{\mathrm{t}}\right)$ was the highest in argic horizons, while in luvic horizons of profiles $\mathrm{P} 4$ and P5, those values were generally lower (Table 3, Fig. 2), which can confirm the effect of lessivage process. Free iron content and the colloidal clay show a significantly positive correlation (Table 4).

The weathering index also reflects the degree of the transformations of the soil substrate, i.e. the release of iron oxides during silicate weathering. In the soils investigated, low $\mathrm{Fe}_{\mathrm{d}}$ / $\mathrm{Fe}_{\mathrm{t}}$ ratios indicate a low degree of weathering. The profile distribution and the content of non-silicate iron $\left(\mathrm{Fe}_{\mathrm{d}}\right)$ depend mainly on weathering intensity and parent material (Okuda et al. 1995). Generally, the largest accumulation occurs in enrichment horizons (Bt) (Table 3), which is also reported by Blume (1988). The lowest $\mathrm{Fe}_{\mathrm{o}}$ contents are found in the parent material except for profile P6 (the least in horizon Et) and P4 (the least in horizon Ap). The dominance of amorphous over crystalline iron oxides suggests a relatively young soil age (McCahon and Munn 1991). In studied soils, due to climatic conditions, the crystalline iron oxides generally dominate over amorphous forms (Cornell and Schwertmann 2003). Temperate climate favours the formation of goethite which forms almost exclusively from ferrihydrite. However, the "ageing" of amorphous iron oxides is governed by many soil and climatic parameters (Stucki et al. 1988). Iron oxide transforming process is related to $\mathrm{pH}$, temperature, the presence of ferrous ions, and the type of anions, such as chloride sulphate and oxyanions. Iron(hydro)oxide system is also redox sensitive (Lin et al. 2008; Das et al. 2011).

The amorphous iron oxides, released during weathering, get crystallized with time. The rate of that process depends considerably on the pedoenvironmental conditions. In the $\mathrm{Bt}$ and $\mathrm{C}$ horizons, amounts of crystalline iron oxides $\left(\mathrm{Fe}_{\mathrm{c}}\right)$ are higher than $\mathrm{Fe}_{\mathrm{o}}$ (Table 3). The highest $\mathrm{Fe}_{\mathrm{c}}$ contents were detected in the illuvial horizons and the parent rock (Table 3). This could due to the inhibiting effect of organic matter on the processes of crystallization (Schwertmann 1988). It has been recognized that the ratio of $\mathrm{Fe}_{\mathrm{d}}$ to $\mathrm{Fe}_{\mathrm{t}}$ is basically controlled by pedogenic weathering.

We determined the iron crystallinity index (Schwertmann 1966) by applying the ratio of amorphous iron to free iron $\mathrm{Fe}_{\mathrm{o}} /$ $\mathrm{Fe}_{\mathrm{d}}$ (Fig. 3), with activity index values to define the interaction between active iron forms and their crystalline forms (Dąbkowska-Naskręt 1996).

Fig. 3 Activity index values

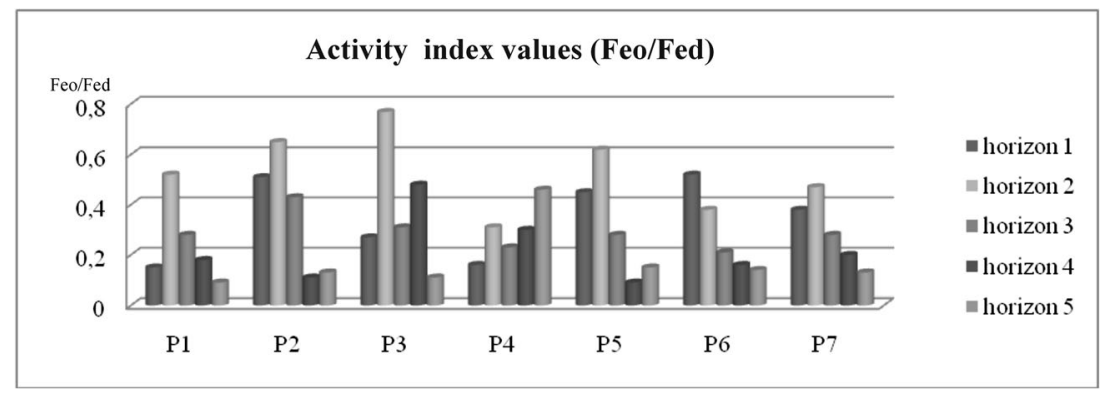


In the soils investigated, the $\mathrm{Fe}_{\mathrm{d}} / \mathrm{Fe}_{\mathrm{d}}$ ratio was the highest in eluvial horizons and the lowest - in parent material, which points to a greater activity of pedogenic iron and a lower degree of iron oxide crystallization in the luvic horizons. Profile $\mathrm{P} 4$ in $\mathrm{C}$ horizon was the only one in which the index value was the highest and in horizon Ap - the lowest (Table 3). The highest value of that index in humus horizons reported by Schwertmann (1966) is not confirmed by the present research (Table 4). Values of activity index in investigated Luvisols may therefore also indicate a similar mineralogical composition of parent materials and similar climatic conditions during their genesis.

The above data on the distribution of different forms of iron within soil profiles suggest genetic non-uniformity of the soil material. To confirm it, another indicator was used, i.e. the distribution of hardly weathered mineral-zircon ( $\mathrm{ZrSiO} 4)$. It was observed (Stiles et al. 2003) that the content of $\mathrm{Zr}$,
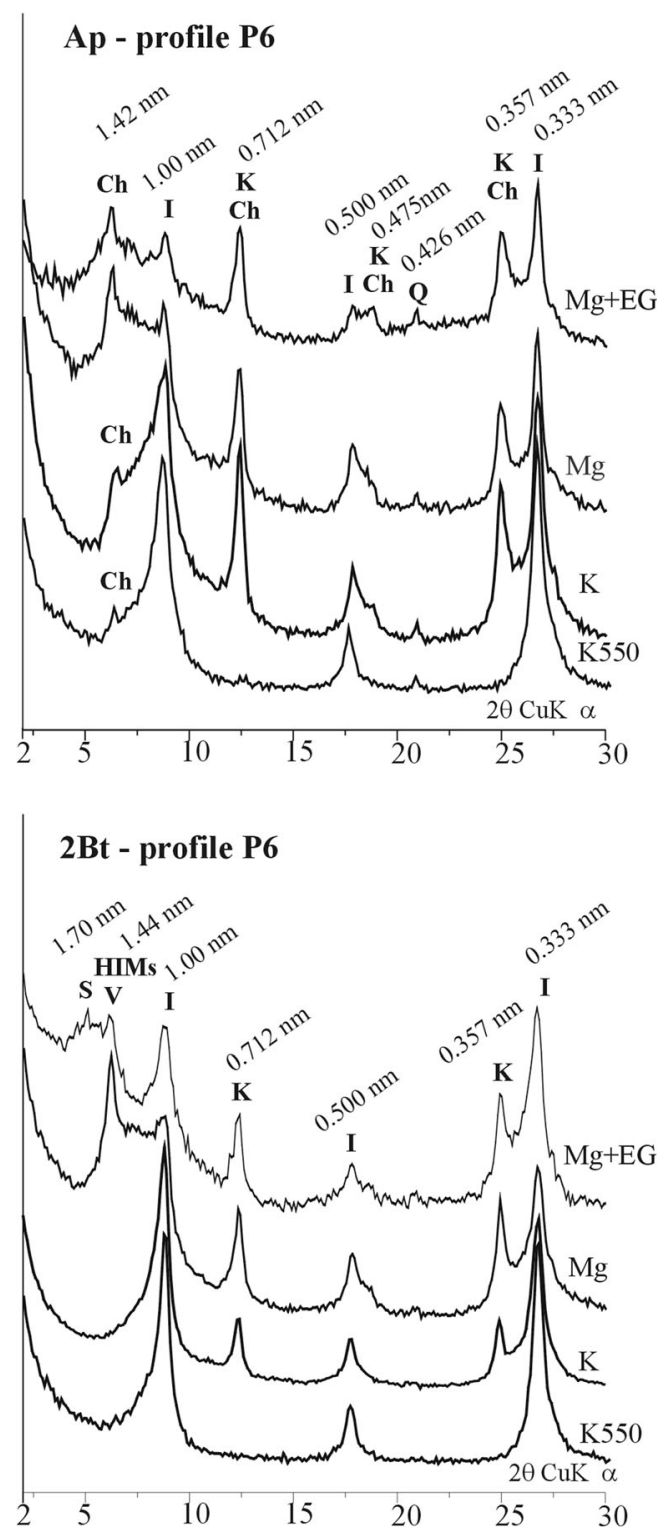

Fig. 4 X-ray diffraction patterns of clay fraction $<2.0 \mu \mathrm{m}$ which occurs in soils principally in the form of $\mathrm{ZrSiO} 4$, is similar in each horizon of soil formed from the uniform material. In other case, it is different in soil strata due to their different origin and, in consequence, different composition in relation to hardly weathered components like zircon.

The boundary between $\mathrm{Zr}$ contents within each soil profile occurs at the same depth as the abrupt change in sand grains contents, i.e. $40-56 \mathrm{~cm}$ (Table 3).

Moreover, mineralogical composition of clay fraction reflects the occurrence of two different strata in studied profiles. On the diffractograms of clay fraction from the topsoil, peaks attributed to illite, kaolinite and chlorite were detected (Fig. 4). In the underlying material illite, smectite and vermiculite together with hydroxy interlayered minerals are present. Moreover, chlorite is absent in the deeper sola due to the disappearance of 1.42-nm peak in the clay fraction saturated with potassium and heated to $550{ }^{\circ} \mathrm{C}$. Vermiculite is also

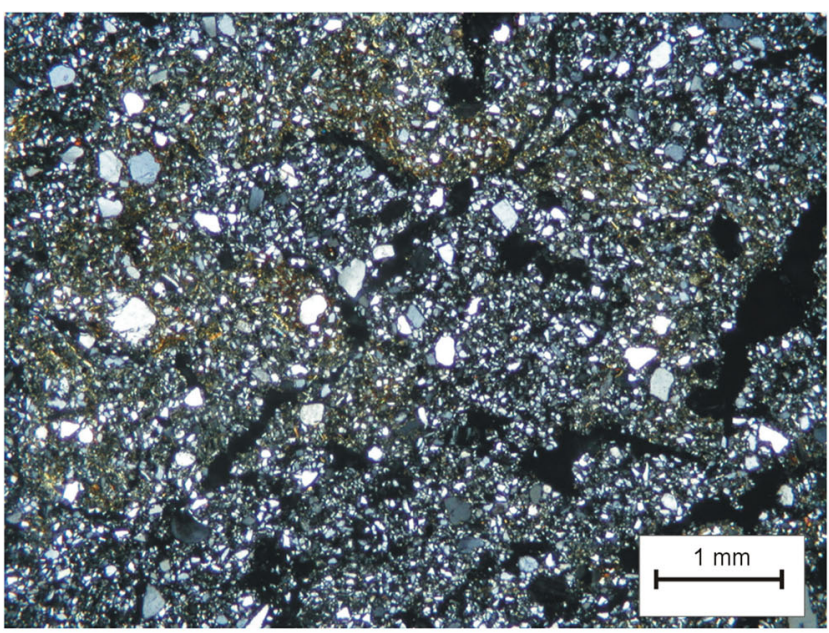

Ap horizon in $\mathrm{P} 6$ profile

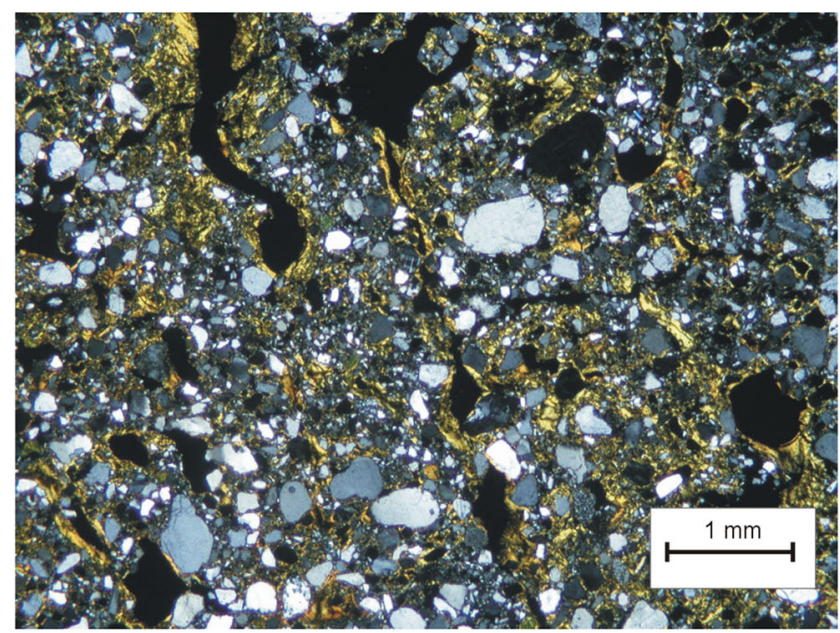

\section{Bt horizon in P6 profile}

Fig. 5 Photomicrographs of the lithogenic and pedogenic features of the soils. Cross-polarized light (XPL) 
present as 1.44-nm peak in Mg-saturated sample contracted to $1.00 \mathrm{~nm}$ after saturation witch potassium (Fig. 4). The occurrence of kaolinite is confirmed by lack of the $0.712-\mathrm{nm}$ peak and the $0.357-\mathrm{nm}$ peak (second-order kaolinite peak) after heating to $550^{\circ} \mathrm{C}$. Thin section analyses of the material from the upper layer confirm the presence of silt particles and loamy material in the deeper part of profile (Fig. 5).

The statistical analysis of the results (Table 4) indicates a significant positive correlation between $\mathrm{Fe}_{\mathrm{t}}$ and clay contents and also between $\mathrm{Fe}_{\mathrm{d}}$ contents and clay fraction, $\mathrm{Fe}_{\mathrm{o}}, \mathrm{Fe}_{\mathrm{d}}$ and $\mathrm{Fe}_{\mathrm{c}}$ with colloidal clay.

\section{Conclusions}

In the soils investigated, Bt horizons are distinctly enriched with $\mathrm{Fe}_{\mathrm{t}}$ and is accompanied by the depletion in luvic horizons, while the pattern of $\mathrm{Fe}_{\mathrm{t}}$ mimics clay distribution, indicating coilluviation of iron and clay.

The weathering index $\left(\mathrm{Fe}_{\mathrm{d}} / \mathrm{Fe}_{\mathrm{t}}\right)$ in the soils assumes the values corresponding to the formations with a low degree of weathering, with the highest values in argic horizons and distinctly lower ratios in the luvic horizons and parent rock, confirming the effect of the process of pedogenesis on the value of that index.

Crystalline iron oxides prevailed over the amorphous forms, which could have been due to the slightly inhibiting effect of organic matter on the processes of crystallization of those compounds in soil.

The iron activity index $\left(\mathrm{Fe}_{\mathrm{o}} / \mathrm{Fe}_{\mathrm{d}}\right)$ was higher in the eluvial horizons and the lowest - in the parent material, which points to a greater activity of pedogenic iron in the luvic horizons of the studied soils. Moreover, it indicates a lower degree of iron oxide crystallization in eluvial (luvic) horizons.

The results of the study showed that iron contents (and their indicators) and iron forms can be used to distinguish soil layers of different origin. Other indicators like zircon distribution and mineralogical composition of clay fraction within soil profile reflecting the occurrence of two layers enhance the above results. The depth distribution of $\mathrm{Fe}_{\mathrm{d}}, \mathrm{Fe}_{\mathrm{o}}$ and $\mathrm{Fe}_{\mathrm{t}}$ within soil profiles indicates that the soil material may be of different lithogenic origin in the studied pedons.

Acknowledgments The study was financed by the Ministry of Science and Higher Education No 0700/P06/2003/25.

Open Access This article is distributed under the terms of the Creative Commons Attribution 4.0 International License (http:// creativecommons.org/licenses/by/4.0/), which permits unrestricted use, distribution, and reproduction in any medium, provided you give appropriate credit to the original author(s) and the source, provide a link to the Creative Commons license, and indicate if changes were made.

\section{References}

Arduino E, Berberis E, Marsan FA, Zanini E, Franchini M (1986) Iron oxides and clay minerals within profiles as indicators of soil age in Northern Italy. Geoderma 37:45-55

Birkeland PW (1999) Soils and Geomorphology, 3rd edn. Oxford Univ. Press, New York

Blume HP (1988) The fate of iron during soil formation in humidtemperate environments. In: Stucki JW, Goodman BA, Schwertmann U (eds) Iron in soils and clay minerals. D. Reidel Publ. Co, Dordrecht, p 749-m

Blume HP, Schwertmann U (1969) Genetic evaluation of profile distribution of Al, Fe, Mn oxides. Soil Sci Am Proc 33:438-444

Cornell RM, Schwertmann U (2003) The iron oxides: structure, properties, reactions, occurrences and uses, 2nd edn. Wiley-VCH, Weinheim, p 664

Crock IG, Severson RC (1980) Four reference soil and rock samples for measuring element availablity from the western energy regions. Geol Survey Circ 841:1-16

Dąbkowska- Naskręt H, Jaworska H (1997) Lessives soils formed from silt deposits from PojezierzeChelminsko- Dobrzyńskie and Wysoczyzna Kaliska region. Part II. Lithogenic uniformity investigations on the base of granulometric composition analyses. Soil Sci. Annual, XLVIII 3/4:123-136

Dąbkowska-Naskręt H (1996) Free iron oxides and their effect on the total surface area of alluvial soils. Soil Sci Annual 47(3/4):23-29

Das D, Hendry MJ, Essilfie- Dughan J (2011) Trasformation of two line ferrihydrite to goethite and hematite as a function of $\mathrm{pH}$ and temperature. Environ Sci Technol 45:268-275

Deng H, Åström M, Björklund A (1998) Geochemical and mineralogical properties of sulfide-bearing fine-grained sediments in Finland. Environ Geol 36:37-44

Duchaufour PH, Sochiers B (1978) Role of iron and clay in genesis of acid soils. Soil Sci 88(6):305-312

Fitzpatrick EA (1984) Soil micromorphology. Chapman and Hall Press, London, $\mathrm{p} 433$

Flint RF (1971) Glacial and quaternary geology. Wiley, New York, p 892

Haynes RJ (2005) Labile organic matter fractions as central components of the quality of agricultural soils: an overview. Adv Agron 85:221268

IUSS Working Group WRB (2007) World Reference Base for Soil Resources 2006. first update. 2007. World Soil Resources Reports No. 103. FAO, Rome, p 116

Jaworska H, Dąbkowska-Naskręt H, Kobierski M (2014) The influence of litho- and pedogenesis processes on the soil cover of selected area of Vistula glaciations based on the distribution of titanium and zirconium. Geol Quat 58(4):685-694

Kabata-Pendias A, Pendias H (2010) Biogeochemistry of trace elements. Lewis Publ, Boca Raton

Kopp D, Kowalkowski A (1990) Cryogenic and pedogenic perstruction in tertiary and quaternary deposits, as exemplified in the outcrop of Sternebeck. Quatern Stud Pol 9:51-71

Kühn P (2001) Grundlegende Voraussetzungen bodengenetischer Vergleichsuntersuchungen: Theorie und Anwendung. Greisfwald Geogr Arb 23:133-153

Kühn P (2003) Micromorphology and Late Glacial/Holocen genesis of Luvisols in Mecklenburg-Vorpommern (NE-Germany). Catena 54: 537-555

Lin H, Guo H, Li P (2008) The transformation of ferrihydrite in the presence of trace Fe (II): the effect of the anionic media. J. Solid State Chem 181:26666: 2671

Lindner L (1984) An outline of Pleistocene chronostratigraphy in Poland. Acta Geol Pol 34:1

Lindner L (1992) QUATERNARY - deposits, test methods. PAE Warszawa 21-25:574 
Marks L (2002) Last glacial maximum in Poland. Quat Sci Rev 21:103110

McCahon TJ, Munn LC (1991) Soils developed in late Pleistocene till, medicine Bow Mountains, Wyoming. Soil Sci 152(5):377-388

McFadden LD, Hendricks DM (1985) Changes in the content and composition of pedogenic iron oxyhydoxides in a chronosequence of soils in Southern California. Quat Res 23:189-204

Mehra OP, Jackson ML (1960) Iron oxide removal from soils and clays by dithionite- citrate system buffered with sodium dicarbonate. Clay Clay Miner 7:317-327

Moody LE, Graham RC (1995) Geomorphic and pedogenic evolution in coastal sediments, Central California. Geoderma 67:181-201

Muhs DR, Bettis EA, Been J, Mc Geehin JP (2001) Impact of climate and parent material on chemical weathering in loess-derived soils of the Mississippi River Valley. Soil Sci Soc Am J 65:1761-1777

Okuda I, Okazaki M, Hashitani T (1995) Spatial and temporal variations in the chemical weathering of basaltic pyroclastic materials. Soil Sci Soc Am J 59:887-894

Ranney RW, Beatty MT (1969) Clay translocation and albic tongue formation in two Glossoboralfs of West-Central Wisconsin. Soil Sci Soc Am Proc 33:768-775

Schlichting E, Blume HP (1962) Art und ausmass der veränderung des bestandes mobile oxide in böden aus jungpleistozänem geschiebemergel und ihren horizonten. Z Pflanzenernähr Bodenkd 96:144-156

Schwertmann U (1966) Inhibitory effect of soil organic matter on the crystallization of amorphous ferrichydroxide. Nature 212:645-646
Schwertmann U (1988) Occurence and formation of iron oxides in various pedoenvironments,[In]: Iron in Soils and Clay Minerals. 261301. NATO

Schwertmann U, Cornell RM (1991) Iron oxides in the laboratory. VCH Publishers, New York

Stiles CA, Mora CI, Driese SG (2003) Pedogenic processes and do main boundaries in a Vertisol climosequence: evidence from titanium and zirconium distribution and morphology. Geoderma 116:279-299

Stoops G (2003) Guidelines for analysis and description of soil and regolith thin sections. Soil Science Society of America, Madison, p 184

Stucki JW, Goodman BA, Schwertmann U (eds) (1988) Iron in soils and clay minerals. NATO ASJ series. Reidel Publishing Company, Dordrecht, $\mathrm{p} 893$

Tack FMG, Verloo MG, Van Mechelen L, Van Ranst E (1997) Baseline concentration of trace elements as a function of clay and organic carbon contents in soil in Flanders (Belgium). Sci Total Environ 201:113-123

Wagner S, Constantini EA, Sauer D, Stahr K (2007) Soil genesis in a marine terrace sequence of Sicily, Italy. Rev Mex Cie Geol 24:247260

Wang Z-P, Shi LL, Chen GS, Cheng KL (2000) Multivariate spectrofluorimetry of ultratrace zirconium (IV) assisted by several chemometrics methods. Talanta 51:31

Waychunas GA, Kim CS, Banfield JF (2005) Nanoparticulate iron oxide minerals in soils and sediments: uniqueproperties and contaminant scavenging mechanisms. J Nanoparticle Res 7:409-433

Wysota W, Molewski P, Sokołowski RJ (2008) Vistula lobe dynamics during the last glaciation in the light of new research. Landform Anal 19:264-266 